\title{
ОКСИДАНТНО-АНТИОКСИДАНТНА СИСТЕМА ПРИ ХРОНІЧНОМУ ОБСТРУКТИВНОМУ ЗАХВОРЮВАННІ ЛЕГЕНЬ ПРОФЕСІЙНОЇ ЕТІОЛОГІЇ
}

Вступ. Основною причиною неспроможності механізмів специфрічного та неспецифрічного захисту організму при багатьох захворюваннях і патологічних станах є дисбаланс у системі прооксиданти - антиоксиданти. Суттєвий дисбаланс у ній супроводжується розвитком оксидативного стресу з його патологічними складовими. Наявність оксидативного стресу відмічено при ряді фрізіологічних та багатьох патологічних станах. Не є винятком і таке розповсюджене серед працівників гірничодобувної промисловості захворювання, як хронічне обструктивне захворювання легень профресійної етіології.

Мета дослідження - оцінити особливості та направленість зрушень окремих показників оксидантно-антиоксидантної системи при хронічному обструктивному захворюванні легень профресійноїетіології.

Методи дослідження. Проаналізовано результати досліджень венозної крові 170 працівників гірничодобувної промисловості, хворих на хронічне обструктивне захворювання легень із різним ступенем тяжкості. Серед пацієнтів 60 осіб мали II стадію захворювання, 56 осіб - III стадію, 54 практично здорових особи становили контрольну групу. Стан окиснення ліпідів у сироватці хворих оцінювали за вмістом ТБК-активних продуктів їх пероксидації, стан системи антиоксидантного захисту - за вмістом або активністю ряду компонентів первинного захисту (ензимів супероксиддисмутази, каталази, глутатіонпероксидази, церулоплазміну і несерментативних низькомолекулярних сполук).

Результати й обговорення. Підвищення рівня ТБК-активних продуктів і зниження загальної антиоксидантної активності плазми свідчили про поглиблення оксидативного стресу. При хронічному обструктивному захворюванні легень профресійної етіології відбувались виснаження захисних можливостей системи антиоксидантного захисту, порушення балансу між генерацією та елімінацією активних кисневих радикалів. Звідси дефріцит антиоксидантного захисту є, вочевидь, одним із фракторів, що провокують тяжкий перебіг та прогресування хронічного обструктивного захворювання легень профресійної етіології.

Висновки. При перебігу хронічного обструктивного захворювання легень професійної етіології різного ступеня тяжкості посилюються процеси пероксидного окиснення ліпідів. Дані порушення відбуваються на тлі пригнічення системи антиоксидантного захисту. Це супроводжується розладом у системі глутатіону.

КЛЮЧОВІ СЛОВА: окисно-відновний гомеостаз; оксидативний стрес; антиоксидантний захист; хронічне обструктивне захворювання легень; професійна етіологія.

ВСТУП. Проблеми хронічних хвороб органів дихання набувають у всьому світі не лише медичного та наукового, але і соціально-економічного значення. Неухильне зростання кількості хворих на хронічне обструктивне захворювання легень (ХОЗЛ) відмічають як в економічно розвинених, так і в країнах, що розвиваються. Це захворювання є однією з основних причин тимчасової непрацездатності, інвалідності та смертності населення [1].

В основі прогресуючої обструкції дихальних шляхів лежить хронічний запальний процес. Він розвивається у відповідь на дію аерополютантів (с) В. В. Івчук, Т. А. Ковальчук, 2019.
3 порушенням балансу між активністю системи прооксиданти - антиоксиданти, протеолітичних і антипротеолітичних процесів, про- та протизапальних фракторів імунної системи [2, 3].

Оксидативний стрес розглядають як зрушення прооксидантно-антиоксидантної рівноваги в бік прооксидантної реактивності на тлі послаблення резервів антиоксидантного захисту. Дисбаланс у системі оксидативний стрес-антиоксидантний захист є однією з патологічних ланок багатьох хронічних захворювань, зокрема ХОЗЛ просресійної етіології [4-6]. Чутливість органів дихання до оксидативного стресу зумовлена багатьма фракторами. Дихальна система підда- 
ється постійному безпосередньому впливу екзогенних оксидантів, що містяться в повітрі промислової робочої зони і можуть підтримувати хронічну запальну реакцію, яка тривалий час клінічно не проявляється. До механізмів, що сприяють активації процесів пероксидного окиснення ліпідів (ПОЛ) при ХОЗЛ, належать запалення, гіпоксія, промислові полютанти, гіповітаміноз, ендогенна інтоксикація, психоемоційний стрес, перевантаження, лікарські засоби $[7,8]$.

У зв'язку з морфологічними та фрункціональними особливостями в респіраторному тракті існує висока вірогідність ендогенного гіперпродукування оксидантів. Ненасичені жирні кислоти легеневої тканини слугують субстратом для реакцій ПОЛ. Різноманітні полютанти та мікроорганізми викликають активацію фрагоцитів. При цьому виробляється значна кількість активних форм кисню [4, 9]. Вони за фрізіологічних умов виконують важливі регуляторні та метаболічні фрункції в організмі. За їх допомогою відбуваються регуляція біоенергетичних процесів, окиснення ксенобіотиків, процеси бактерицидного захисту, клітинного поділу, апоптозу. Але при надлишку активних фрорм кисню вони можуть стати фракторами прогресування хронічної запальної реакції і розвитку синдрому системної запальної відповіді зі зростанням трофологічної недостатності та інсулінорезистентності [5, 7]. Пероксидні сполуки, що утворюються в результаті ПОЛ, зокрема пероксинітрит, чинять гальмівний вплив на інгібітори протеаз та сприяють підвищенню протеазної активності біологічних середовищ, фрормуванню незворотної бронхіальної обструкції при ХОЗЛ $[10,11]$. Під дією пероксиду водню спостерігають також зниження концентрації та адренергічної активності $\beta$-адренорецепторів у мембранах міоцитів дихальних шляхів, що викликає бронхообструкцію при ХОЗЛ $[2,5]$.

У таких випадках виникає "порочне коло". Гіпоксія призводить до подальшого посилення процесів ПОЛ та окиснювальної модифікації білків, їх глікозилювання, забезпечує збільшення модифікованої атерогенної фрракції ліпопротеїнів. У подальшому відбувається зростання гіпоксичних та ішемічних змін в органах і тканинах. Погіршення мікроциркуляції, метаболічний ацидоз, тканинна гіпоксія знижують активність макрофрагів, підвищують апоптотичну активність клітин, що є патогенетичною ланкою хронічної запальної реакції, яка перебігає латентно $[4,8]$. При цьому не до кінця вивченими залишаються питання щодо особливостей метаболічних зрушень при розвитку та перебігу ХОЗЛ професійної етіології. Знання особливостей зміни стану окремих компонентів системи антиоксидантного захисту та рівня оксидативного стресу важливі для призначення еорективного лікування і визначення прогнозу захворювання.

Мета дослідження - оцінити особливості та направленість зрушень окремих показників оксидантно-антиоксидантної системи при хронічному обструктивному захворюванні легень профресійної етіології.

МЕТОДИ ДОСЛІДЖЕННЯ. Проаналізовано 170 результатів лабораторних досліджень хворих на ХОЗЛ працівників гірничодобувної промисловості. Середній вік хворих становив $(61,32 \pm 1,80)$ року. Діагноз ХОЗЛ було встановлено на підставі міжнародних критеріїв GOLD та наказу МОЗ України від 27 червня 2013 р. № 555 “Про затвердження та впровадження медико-технологічних документів зі стандартизації медичної допомоги при хронічному обструктивному захворюванні легень". Клінічну групу становили 60 пацієнтів із захворюванням середньої тяжкості (ХОЗЛ II) і 56 пацієнтів з тяжкою стадією перебігу захворювання (ХОЗЛ III), контрольну 54 працівники гірничодобувної промисловості без патології органів дихання. Дослідження виконано згідно з Гельсінською декларацією Всесвітньої медичної асоціації “Етичні принципи проведення медичних досліджень за участі людини в якості суб'єкту" (червень 1964 р., Гельсінкі, Фінляндія) з поправками (жовтень 2013 р., Форталеза, Бразилія), і його схвалив етичний комітет.

Забір венозної крові здійснювали зранку натщесерце. Стан окиснення ліпідів у сироватці хворих оцінювали за вмістом продуктів їх пероксидації. Вміст ТБК-активних продуктів ПОЛ визначали колориметричним методом за реакцією з 2-тіобарбітуровою кислотою [12]. Стан системи антиоксидантного захисту (АОЗ) оцінювали за вмістом або активністю ряду компонентів первинного захисту - ензимів супероксиддисмутази (СОД), каталази (КАТ), глутатіонпероксидази (ГП), церулоплазміну (ЦП) і нефрерментативних низькомолекулярних сполук. Активність сумарної СОД (КФ 1.15.1.1) у плазмі оцінювали за ступенем гальмування реакції окиснення кверцетину [13], активність КАТ (КФ 1.11.1.6) у сироватці - за її здатністю розкладати пероксид водню, про що судили за величиною неутилізованого пероксиду водню, який утворює стійкий забарвлений комплекс із солями молібдату амонію [14]. Активність ГП (КФ1.11.1.9) визначали за розщепленням гідроперекису третбутилу, використовуючи як субстрат відновлений глутатіон, вміст ЦП - за окисненням френілендіаміндигідрохлориду за присутності ЦП [15]. Вміст низькомолекулярних водорозчинних антиоксидантів оцінювали за кількістю небілкових тіоло- 
вих груп (НТГ) еритроцитів [15]. Визначення цих груп базується на здатності низькомолекулярних тіолових сполук при взаємодії з дитіонітробензойною кислотою утворювати стійку забарвлену сполуку [16].

Статистичну обробку отриманих даних проводили 3 використанням пакета програм Statistica 6.0 ("StatSoft", США). Знаходили середнє арифметичне значення (М), помилку середнього арифметичного значення (m). Результати представляли у вигляді $\mathrm{M} \pm \mathrm{m}$. Достовірність відмінностей середніх величин визначали за t-критерієм Стьюдента. Відмінності вважали статистично значимими при $р<0,05$.

РЕЗУЛЬТАТИ Й ОБГОВОРЕННЯ. У ВСіХ ХВОрих відмічали збільшення продуктів ПОЛ на тлі підвищення активності ГП і вмісту ЦП, зниження активності СОД та коесріцієнта СОД/КАТ, що свідчило про напруження оксидантно-антиоксидантної системи. У хворих на ХОЗЛ професійної етіології розвивався оксидативний стрес (рис.).

Отримані дані вказували на те, що напруження окиснювальних процесів і системи АОЗ притаманне обом групам. Водночас зміни у Хворих на ХОЗЛ III стадії мали більш виражений характер. Зокрема, рівень ТБК-активних продуктів зростав в 1,8 раза при ХОЗЛ II і в 1,9 раза при ХОЗЛ ІІІ порівняно з контрольною групою.

У пацієнтів із ХОЗЛ II активність КАТ перевищувала показники контролю у 2,2 раза, а при ХОЗЛ III - в 3,7 раза (табл.).

Середні значення активності СОД були достовірно нижчими за контрольні в обох групах хворих, однак між собою значимо не відрізнялися. Додатково було розраховано коефіцієнт СОД/ КАТ, що характеризує роботу фрізіологічного каскаду антиоксидантних ензимів. Потрібно також відмітити порушення спряженої дії ензимів СОД і КАТ. Це проявлялося зниженням коефріцієнта СОД/КАТ у середньому до 7,10 у пацієнтів із ХОЗЛ II і до 4,72 у пацієнтів із ХОЗЛ ІІІ порівняно 3 25,19 у контрольній групі. При ХОЗЛ II

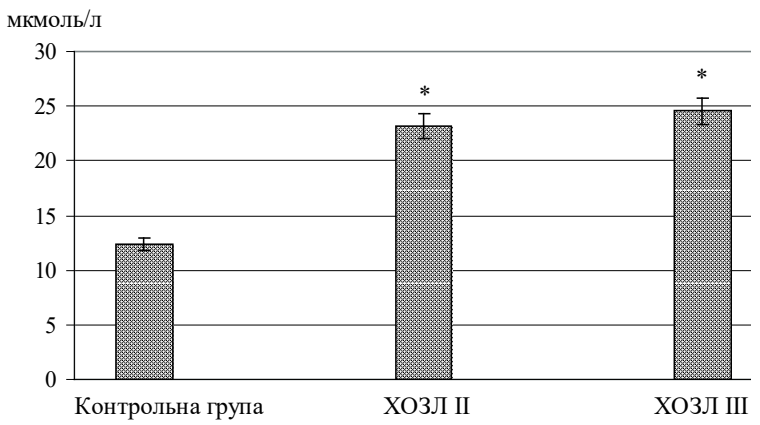

Рис. Вміст ТБК-активних продуктів пероксидного окиснення ліпідів у сироватці хворих на хронічне обструктивне захворювання легень професійної етіології різного ступеня тяжкості (* - різниця достовірна між контрольною групою і хворими).

вміст ЦП у хворих більш ніж у 2,0 рази перевищував середнє значення в контрольній групі. Паралельно зі збільшенням ступеня тяжкості перебігу ХОЗЛ профресійної етіології спостерігали протилежну тенденцію - вміст ЦП дещо зменшувався порівняно $з$ групою ХОЗЛ II.

Тенденція до збільшення вмісту ТБК-активних продуктів ПОЛ при зростанні ступеня тяжкості перебігу ХОЗЛ, на наш погляд, свідчить про посилення напруження окисних процесів. Аналіз змін показників АОЗ показав, що зростання ступеня тяжкості перебігу ХОЗЛ профресійної етіології супроводжується збільшенням активності КАТ і зменшенням вмісту НТГ. Інтерпретувати результати, що стосуються ЦП, достатньо складно. Відомо, що він інгібує процес ПОЛ, який каталізують іони заліза. Церулоплазмін також нейтралізує супероксидний аніон-радикал та ряд інших активних кисневих радикалів (АКР) [17]. Антиоксидантна роль ЦП реалізується через його оксидазну активність, що направлена на ароматичні аміни і феноли, а також за допомогою фероксидазної активності $[17,18]$. Достовірне підвищення вмісту ЦП у хворих на ХОЗЛ просресійної етіології, ймовірно, є компенсаторною антиоксидантною реакцією. Відмічене незначне зниження вмісту ЦП при зростанні ступеня тяжкості перебігу ХОЗЛ, на наш погляд, може бути

Таблиця - Показники антиоксидантного захисту у хворих на хронічне обструктивне захворювання легень професійної етіології різного ступеня тяжкості (M $\pm \mathrm{m})$

\begin{tabular}{|c|c|c|c|}
\hline Показник & $\begin{array}{c}\text { Контрольна група } \\
(n=54)\end{array}$ & $\begin{array}{c}\text { ХОЗЛ II } \\
(\mathrm{n}=60)\end{array}$ & $\begin{array}{l}\text { ХОЗЛ III } \\
(\mathrm{n}=56)\end{array}$ \\
\hline СОД, ум. од. акт./мл & $46,11 \pm 2,31$ & $29,68 \pm 2,67^{*}$ & $32,57 \pm 5,22^{*}$ \\
\hline СОД/КАТ & 25,19 & 7,10 & 4,72 \\
\hline НТГ, ммоль/л & $0,38 \pm 0,04$ & $0,19 \pm 0,02^{*}$ & $0,22 \pm 0,05^{\star}$ \\
\hline ГП, ммоль/мЛ & $0,67 \pm 0,03$ & $0,98 \pm 0,06^{*}$ & $0,65 \pm 0,07^{\#}$ \\
\hline
\end{tabular}

Примітки:

1. * - різниця достовірна порівняно з контрольною групою $(p<0,05)$.

2. \# - різниця достовірна порівняно з групою ХОЗЛ II $(p<0,05)$. 
наслідком активного самоокиснення сполук 3 вільними тіоловими групами. Цей процес перебігає з обов'язковою участю іонів міді. Як відомо, майже 95 \% міді входять до складу ЦП [18]. Вміст НТГ у пацієнтів зменшився майже у 2,0 рази при ХОЗЛ ІІ. При зростанні ступеня тяжкості перебігу ХОЗЛ профресійної етіології спостерігали тенденцію до незначного підвищення рівня НТГ порівняно 3 ХОЗЛ II, що, ймовірно, пов'язано зі зниженням активності ГП, субстратом якої $\epsilon$ глутатіон. Активність СОД у хворих обох груп статистично значимо була меншою, ніж у контрольній групі. Достовірних відмінностей цього показника залежно від ступеня тяжкості перебігу ХОЗЛ не виявлено. Висока варіабельність значень активності СОД може бути наслідком нездатності підтримки бар'єрних фрункцій еритроцитарною мембраною та її ушкодження продуктами ПОЛ. Активність КАТ статистично значимо збільшувалась при зростанні ступеня тяжкості перебігу ХОЗЛ профресійної етіології. Якщо при ХОЗЛ II відмічали тенденцію до зростання активності КАТ, то при ХОЗЛ ІІІ вона була достовірно вищою порівняно з ХОЗЛ II.

Активність ГП у хворих на ХОЗЛ середнього ступеня тяжкості підвищувалась порівняно 3 показниками контрольної групи, що свідчило про адекватну відповідь системи АОЗ. При тяжкому перебігу захворювання вона була дещо нижчою, ніж при ХОЗЛ II, тобто не забезпечувала еорективного захисту від зростання продукції АКР. Глутатіонпероксидаза - це антиоксидант, що відновлює пероксидні ліпіди та пероксид водню до відповідних спиртів і відіграє ключову роль у механізмі внутрішньоклітинної дезінтоксикації. Каталаза впливає виключно на пероксид водню. Однак, незважаючи на досить високу каталітичну активність КАТ, відносно пероксиду водню, її константа Міхаеліса у 2-3 рази нижча, ніж у ГП [19]. Крім того, каталаза, на відміну від ГП, не може відновлювати пероксидів ліпідів. Таким чином, відмічене компенсаторне підвищення активності каталази без синергічної зміни ГП не може забезпечити ефективного захисту організму від АКР при тяжкому ступені перебігу ХОЗЛ профресійної етіології. Досліджені антиоксидантні ензими утворюють єдиний метаболічний ланцюг. У ньому продукт першої реакції є субстратом наступної. Зокрема, КАТ і ГП здатні видаляти надлишок пероксиду водню, що утворюється з участю СОД. Для нормального фрункціонування системи в цілому необхідним $є$ баланс активності окремих елементів ланцюга. Про порушення балансу системи свідчить зниження коефріцієнта СОД/КАТ, що також чітко корелює зі ступенем тяжкості перебігу ХОЗЛ професійної етіології.

Таким чином, підвищення вмісту ТБК-активних продуктів ПОЛ і зниження активності системи АОЗ свідчать про поглиблення оксидативного стресу. При ХОЗЛ профресійної етіології відбуваються виснаження захисних можливостей системи AO3, порушення балансу між генераці$€ ю$ та елімінацією АКР. Звідси дефріцит АОЗ $€$, вочевидь, одним із фракторів, що провокують тяжкий перебіг та прогресування ХОЗЛ профресійної етіології.

ВИСНОВКИ. Патологічні зміни організму, що виникають за перебігу ХОЗЛ профресійної етіології, є підґрунтям для розвитку вираженого оксидативного стресу. Відбувається вибіркове пригнічення продукування глутатіонпероксидази. Підвищення активності каталази без синергічної дії глутатіонпероксидази не забезпечує есрективного захисту організму від активних радикалів кисню.

Перспективи подальших досліджень полягають у з'ясуванні ролі порушення обмінних процесів у розвитку та прогресуванні хронічного обструктивного захворювання легень професійної етіології та пошуку шляхів їх корекції.

\section{СПИСОК ЛІТЕРАТУРИ}

1. Global Strategy for the Diagnosis, Management, and Prevention of Chronic Obstructive Lung Disease: The GOLD Science Committee Report 2019 / D. Singh, A. Agusti, A. Anzueto [et al.] // Eur. Respir. J. - 2019. No. 5. - P. 211-228.

2. Choudhury G. Role of inflammation and oxidative stress in the pathology of ageing in COPD: potential therapeutic interventions / G. Choudhury, W. MacNee // COPD: Journal of Chronic Obstructive Pulmonary Disease. $-2017 .-14$, No. 1. - P. 122-135.

3. Івчук В. В. Характеристика клітинного складу мокротиння хворих на хронічне обструктивне захво- рювання легень профресійної етіології / В. В. Івчук, Т. Ю. Коптєва, Т. А. Ковальчук // Мед. перспективи. 2018. - 23, № 3 (1). - C. 88-94.

4. Fischer B. M. COPD: balancing oxidants and antioxidants / B. M. Fischer, J. A. Voynow, A. J. Ghio // International Journal of Chronic Obstructive Pulmonary Disease. - 2015. - 10. - P. 261.

5. Antus B. Oxidative stress in COPD: molecular background and clinical monitoring / B. Antus, Z. Kardos // Current Medicinal Chemistry. - 2015. - 22, No. 5. P. 627-650. 
6. Association between work and chronic obstructive pulmonary disease (COPD) / $\mathrm{H}$. van der Molen, G. de Groene, C. Hulshof [et al.] // Journal of Clinical Medicine. 2018. - 7, No. 10. - P. 335.

7. The role of ROS in COPD progression and therapeutic strategies / R. Bathri, P. Bose, V. S. Gujar [et al.] // Reactive Oxygen Species. - 2017. - 4. - P. 237-250.

8. Prevalence and etiological profile of chronic obstructive pulmonary disease in nonsmokers / T. Mahmood R. K. Singh, S. Kant [et al.] // Lung India: Official Organ of Indian Chest Society. - 2017. - 34, No. 2. - P. 122.

9. The effect of conjugated linoleic acid on oxidative stress and matrix metalloproteinases 2 and 9 in patients with COPD / S. Matin, A. Nemati, H. Ghobadi [et al.] // International Journal of Chronic Obstructive Pulmonary Disease. - 2018. - 13. - P. 1449.

10. Sato T. Pathogenesis of COPD 3: Oxidative stress - is there a possibility of developing new Drugs from the standpoint of this pathogenetic mechanism? T. Sato, K. Seyama // Chronic Obstructive Pulmonary Disease. - Singapore: Springer, 2017. - P. 73-93.

11. COPD and stroke: are systemic inflammation and oxidative stress the missing links? / V. Austin, P. J. Crack, S. Bozinovski [et al.] // Clinical Science. 2016. - 130, No. 13. - P. 1039-1050.

12. Андреева Л. И. Модифрикация метода определения перекисей липидов в тесте с тиобарбитуро- вой кислотой / Л. И. Андреева, Л. А. Кожемякин, А. А. Кишкун // Лаб. дело. - 1988. - № 11. - С. 41-43.

13. Костюк В. А. Простой и чувствительный метод определения супероксиддисмутазы, основанный на реакции окисления кверцетина / В. А. Костюк, А. И. Потапович, Ж. В. Ковалева // Вопросы медицинской химии. - 1990. - № 32. - С. 88-91.

14. Метод определения активности каталазы / М. А. Королюк, А. И. Иванова, И. Г. Майорова [и др.] // Лаб. дело. - 1988. - № 1. - С. 16-19.

15. Арутюнян А. В. Методы оценки свободно-радикального окисления и антиоксидантной системы организма / А. В. Арутюнян, Е. Е. Дубинина, Н. Н. Зыбина. - СПб. : Фолиант, 2000. - 104 с.

16. Медицинские лабораторные технологии и диагностика : справочник : в 2 т. / под ред. А. И. Карпищенко. - СПб. : Интермедика, 1998. - 2. - С. 72-73.

17. Ehrenwald E. Intact human ceruloplasmin oxidatively modifies low density lipoprotein / E. Ehrenwald, G. M. Chisolm, P. L. Fox // The Journal of Clinical Investigation. - 1994. - No. 93 (4). - P. 1493-1501.

18. Role of bilirubin, vitamin $C$ and ceruloplasmin as antioxidants on coronary artery disease / V. K. Verma, V. Ramesh, S. Tewari [et al.] // Ind. J. Clin. Biochem. 2005. - No. 20 (2). - P. 68-74.

19. Loscalo J. The oxidant stress of hyperhomocysteinemia / J. Loscalo // J. Clin. Invest. - 1996. - 98. P. 5-7.

\section{REFERENCES}

1. Singh, D., Agusti, A., Anzueto, A., \& Barnes, P.J. (2019). Global Strategy for the Diagnosis, Management, and Prevention of Chronic Obstructive Lung Disease: The GOLD Science Committee Report 2019. Eur. Respir. J., 5, 211-228.

2. Choudhury, G., \& MacNee, W. (2017). Role of inflammation and oxidative stress in the pathology of ageing in COPD: potential therapeutic interventions. COPD. Journal of Chronic Obstructive Pulmonary Disease, 14 (1), 122-135.

3. Ivchuk, V.V., Kopteva, T.Yu., \& Kovalchuk T.A. (2018). Kharakterystyka klitynnoho skladu mokrotynnia khvorykh na khronichne obstruktyvne zakhvoriuvannia lehen profesiinoi etiolohii [Characterization of the cellular composition of sputum of patients with chronic obstructive pulmonary disease of occupational etiology]. Medychni perspektyvy - Medical Perspectives, 23, 3 (1), 88-94 [in Ukrainian].

4. Fischer, B.M., Voynow, J.A., \& Ghio, A.J. (2015). COPD: balancing oxidants and antioxidants. International Journal of Chronic Obstructive Pulmonary Disease, 10, 261.

5. Antus, B., \& Kardos, Z. (2015). Oxidative stress in COPD: molecular background and clinical monitoring. Current Medicinal Chemistry, 22 (5), 627-650.

6. van der Molen, H., de Groene, G., Hulshof, C., \& Frings-Dresen, M. (2018). Association between work and chronic obstructive pulmonary disease (COPD). Journal of Clinical Medicine, 7 (10), 335.
7. Bathri, R., Bose, P., Gujar, V. S., \& Kumar, L. (2017). The role of ROS in COPD progression and therapeutic strategies. Reactive Oxygen Species, 4, 237-250.

8. Mahmood, T., Singh, R.K., Kant, S., Shukla, A.D., Chandra, A., \& Srivastava, R.K. (2017). Prevalence and etiological profile of chronic obstructive pulmonary disease in nonsmokers. Lung India: Official Organ of Indian Chest Society, 34 (2), 122.

9. Matin, S., Nemati, A., Ghobadi, H., AlipanahMoghadam, R., \& Rezagholizadeh, L. (2018). The effect of conjugated linoleic acid on oxidative stress and matrix metalloproteinases 2 and 9 in patients with COPD. International Journal of Chronic Obstructive Pulmonary Disease, 13, 1449.

10. Sato, T., \& Seyama, K. (2017). Pathogenesis of COPD 3: Oxidative stress - is there a possibility of developing new drugs from the standpoint of this pathogenetic mechanism? In Chronic Obstructive Pulmonary Disease. Singapore: Springer.

11. Austin, V., Crack, P.J., Bozinovski, S., Miller, A.A., \& Vlahos, R. (2016). COPD and stroke: are systemic inflammation and oxidative stress the missing links? Clinical Science, 130 (13), 1039-1050.

12. Andreeva, L.I., Kozhemyakin, L.A., \& Kishkun, A.A. (1988) Modifikatsiya metoda opredeleniya perekisey lipidov v teste $s$ tiobarbiturovoy kislotoy [Modification of the method for determining lipid peroxides in a test with thiobarbituric acid]. Lab. delo - Laboratory Work, 11, 4143 [in Russian]. 
13. Kostyuk, V.A., Potapovich, A.I., \& Kovaleva, Zh.V. (1990). Prostoy i chuvstvitelnyy metod opredeleniya superoksiddismutazy, osnovannoy na reaktsii okisleniya kvertsetina [A simple and sensitive method for the determination of superoxide dismutase, based on the reaction of quercetin oxidation]. Voprosy meditsinskoy khimii - Questions of Medical Chemistry, 32, 88-91 [in Russian].

14. Korolyuk, M.A., Ivanova, L.I., Mayorova, I.G., \& Tokareva, V.E. Metod opredeleniya aktivnosti katalazy [Method for the determination of catalase activity]. Lab. delo - Laboratory Work, 1, 16-19 [in Russian].

15. Arutyunyan, A.V., Dubinina, E.E., \& Zybina, N.N. (2000). Metody otsenki svobodno-radikalnogo okisleniya $i$ antioksidantnoy sistemy organizma [Methods for evaluating free-radical oxidation and the antioxidant system of the body]. Saint Petersburg: Foliant [in Russian].

16. Karpishchenko, A.I. (1998). Meditsinskie laboratornye tekhnologii i diagnostika [Medical laboratory technologies and diagnostics]. Saint Petersburg: Intermedika [in Russian].

17. Ehrenwald, E., Chisolm, G.M., \& Fox, P.L. (1994). Intact human ceruloplasmin oxidatively modifies low density lipoprotein. The Journal of Clinical Investigation, 93 (4), 1493-1501.

18. Verma, V.K., Ramesh, V., Tewari, S., Gupta, R.K., Sinha, N., \& Pandey, C.M. (2005). Role of bilirubin, vitamin $\mathrm{C}$ and ceruloplasmin as antioxidants on coronary artery disease. Ind. J. Clin. Biochem., 20 (2), 68-74.

19. Loscalo, J. (1996). The oxidant stress of hyperhomocysteinemia J. Clin. Invest., 98, 5-7.

\section{ОКСИДАНТНО-АНТИОКСИДАНТНАЯ СИСТЕМА ПРИ ХРОНИЧЕСКОЙ ОБСТРУКТИВНОЙ БОЛЕЗНИ ЛЕГКИХ ПРОФЕССИОНАЛЬНОЙ ЭТИОЛОГИИ}

Резюме

Вступление. Основной причиной несостоятельности механизмов специфрической и неспецияической защиты организма при многих заболеваниях и патологических состояниях является дисбаланс в системе прооксиданты - антиоксиданты. Существенный дисбаланс в ней сопровождается развитием оксидативного стресса с его патологическими составляющими. Наличие оксидативного стресса отмечено при ряде фризиологических и многих патологических состояниях. Не является исключением и такое распространенное среди работников горнодобывающей промышленности заболевание, как хроническая обструктивная болезнь легких профессиональной этиологии.

Цель исследования - оценить особенности и направленность сдвигов отдельных показателей оксидантно-антиоксидантной системы при хронической обструктивной болезни легких профессиональной этиологии.

Методы исследования. Проанализированы результаты исследований венозной крови 170 работников горнодобывающей промышленности, больных хронической обструктивной болезнью легких с различной степенью тяжести. Среди пациентов 60 лиц имели II стадию заболевания, 56 лиц - III стадию, 54 практически здоровых человека составили контрольную группу. Состояние окисления липидов в сыворотке больных оценивали по содержанию ТБК-активных продуктов их пероксидации, состояние системы антиоксидантной защиты - по содержанию или активности ряда компонентов первичной защиты (энзимов супероксиддисмутазы, каталазы, глутатионпероксидазы, церулоплазмина и неферментативных низкомолекулярных соединений).

Результаты и обсуждение. Повышение уровня ТБК-активных продуктов и снижение общей антиоксидантной активности плазмы свидетельствовали об углублении оксидативного стресса. При хронической обструктивной болезни легких профрессиональной этиологии происходили истощение защитных возможностей системы антиоксидантной защиты, нарушение баланса между генерацией и элиминацией активных кислородных радикалов. Отсюда дефицит антиоксидантной защиты является, очевидно, одним из фракторов, провоцирующих тяжелое течение и прогрессирование хронической обструктивной болезни легких профрессиональной этиологии.

Выводы. При течении хронической обструктивной болезни легких профессиональной этиологии различной степени тяжести усиливаются процессы перекисного окисления липидов. Данные нарушения происходят на фоне угнетения системы антиоксидантной защиты. Это сопровождается расстройством в системе глутатиона.

КЛЮЧЕВЫЕ СЛОВА: окислительно-восстановительный гомеостаз; оксидативный стресс; антиоксидантная защита; хроническая обструктивная болезнь легких; профессиональная этиология. 


\section{OXIDANT AND ANTIOXIDANT SYSTEM IN CHRONIC OBSTRUCTIVE PULMONARY DISEASE OCCUPATIONAL ETIOLOGY}

\section{Summary}

Introduction. The main reason for the failure of the mechanisms of specific and non-specific defense of the body in many diseases and pathological conditions is an imbalance in the system of prooxidants-antioxidants. A significant imbalance in this system is accompanied by the development of oxidative stress with its pathological components. The presence of oxidative stress was observed in a number of physiological and many pathological states. There is no exception and such a common disease among the mining industry workers as chronic obstructive pulmonary disease of occupational etiology.

The aim of the study - to evaluate the features and direction of shifts of individual indicators of the oxidativeantioxidant system in chronic obstructive pulmonary disease of occupational etiology.

Research Methods. The results of venous blood studies of 170 workers in the mining industry in patients with chronic obstructive pulmonary disease with varying degrees of severity are analyzed. Among the patients, 60 people had stage II, 56 people had stage III disease, and 54 practically healthy individuals formed the control group. The state of lipid oxidation in the serum of patients was assessed by the content of TBA-active products of their peroxidation. The state of the antioxidant protection system was assessed by the content or activity of a number of primary protection components - superoxide dismutase, catalase, glutathione peroxidase, ceruloplasmin, and non-enzymatic low molecular weight compounds.

Results and Discussion. An increase in the level of TBA-active products and a decrease in the total antioxidant activity of plasma indicates a deepening of oxidative stress. In chronic obstructive pulmonary disease of occupational etiology, the protective capabilities of the antioxidant defense system are depleted, and the balance between generation and elimination of active oxygen radicals is disturbed. Hence, the lack of antioxidant protection is obviously one of the factors provoking a severe course and progression of chronic obstructive pulmonary disease of occupational etiology.

Conclusions. During the course of chronic obstructive pulmonary disease of occupational etiology of varying degrees of severity, lipid peroxidation processes are enhanced. These violations occur against the background of inhibition of the antioxidant defense system. This is accompanied by a disorder in the glutathione system.

KEY WORDS: redox homeostasis; oxidative stress; antioxidant protection; chronic obstructive pulmonary disease; occupational etiology.

Отримано 15.04.19

Адреса для листування: В. В. Івчук, Український науково-дослідний інститут промислової медицини МОз України, вул. Виноградова, 40, Кривий Ріг, 50096, Україна, e-mail: vitaliy.ivchuk@gmail.com. 